\title{
APPLICATION OF GEOSPATIAL TOOLS TO MONITOR CHANGE IN A MICRO-TIDAL ESTUARY FOR THE PURPOSE OF MANAGEMENT PLANNING
}

\author{
N. Nagabhatla ${ }^{1}$, C. M. Finlayson ${ }^{1}$, S. Seneratna Sellamuttu ${ }^{1}$ and A. Gunawardena ${ }^{2}$ \\ ${ }^{1}$ International Water Management Institute (IWMI), P O Box 2075, Colombo, Sri Lanka \\ ${ }^{2}$ Central Environmental Authority (CEA), No.104, Denzil Kobbekaduwa Mawatha, \\ “Parisara Piyasa”,Battaramulla,Sri Lanka. \\ Accepted 13 May 2008
}

\begin{abstract}
The sustainable management of wetlands requires up-to-date inventory and regular monitoring. Also, the understanding of change dynamics and response of these ecosystems to natural and social pressures provides information and impetus for conservation planning. Earth observation data and geospatial tools have immense potential for developing integrated geospatial models/methods for wetland mapping and change analysis. The present study in a coastal wetland system in Sri Lanka describes an approach to mapping and monitoring of change using a combination of multi-spectral and temporal remote sensing data and the IDRISI-Land Change Modeller (LCM). Socioeconomic data and ancillary details were integrated at different levels of analysis for refinement and validation. A multi-level analysis reflects the present status and highlights the trends of wetland use in the landscape. Along with the participation of the Sri Lanka Environmental Authority (CEA) the biophysical analysis and the socioeconomic components were inter-linked wherein the spatial and the social information are qualitatively and quantitatively integrated to understand the dynamics of change in the micro-tidal estuary.
\end{abstract}

Keywords: Geospatial, socioeconomic, wetland, sustainable, IDRISI-Andes, micro-tidal estuary

\section{INTRODUCTION}

Concern over the increasing impact of human activities on environmental systems has received more global attention and motivated multidisciplinary assessments in order to address the multiple pressures that often interact synergistically or cumulatively (e.g. Millennium Ecosystem Assessment, 2005). Coastal wetlands in many tropical countries are amongst the many ecosystems that are under increasing pressure from rapidly growing human populations and development. This is the case in western Sri Lanka where coastal wetlands are under pressure from increasing commercial and industrial activities, population growth, natural disasters and the overexploitation of natural resources (IUCN Sri Lanka, 2003; ADB, 2005). Monitoring change in such ecosystems and circumstances can be a difficult task - this is the case in many tropical wetlands where ecological change can often lead to socioeconomic concerns (Dahdouh-Guebas et al., 2005). However, the development in recent years of sophisticated geospatial techniques has provided a means to assess the structure, pattern, and environmental processes that operate in such systems. Further, multi-disciplinary and multiscalar approaches can be used to investigate the uncertainties that arise when dealing with complex systems (Nagabhatla et al., 2006; Finlayson, 2007). In response to such needs Finlayson et al., (2002) have emphasised the necessity of integrating approaches for the inventory, assessment and monitoring of tropical wetlands.

With these approaches in mind a framework was developed to investigate the efficacy of integrating geospatial, biophysical and socioeconomic analyses of the pattern of spatial change and its links with the local livelihood activities (agriculture, aquaculture and fishing) in coastal wetlands in western Sri Lanka where most wetland investigations have focussed on one or other aspect only (Hoogvorst, 2003; Bambaradeniya et al., 2002). Nagabhatla et al., (2006) have previously discussed the importance of a holistic undertanding of wetland dynamics as crucial, for long-term sustainable management. This concept is further expanded in this paper with the specific purpose of testing a mutli-disciplinary

*Corresponding author’s email: n.nagabhatla@cgiar.org 
geospatial approach that addresses the environmental issues in the coastal environment as a basis for contributing to the policy debate on the wise use of wetlands.

\section{Background}

The International Water Management Institute (IWMI) has developed a global wetland inventory and mapping project working with partners through the framework of the Ramsar Convention on Wetlands to undertake comprehensive, multiple purpose and multi-scale wetland inventory (Finlayson et al., 2006; Rebelo et al., 2008). A meso-scale component of this project involved an analysis of change in the Muthrajawela MarshNegombo Lagoon (MMNL) wetland complex along the western coast to the north of Colombo in Sri Lanka. The change analysis was undertaken in collaboration with the Sri Lankan Central Environmental Authority (CEA) which has led the development of a national wetland inventory (CEA, 2006).

In doing this the threats to the wetland complex were categorised as either 'ecological' or 'socio-economic' with the former referring to habitat degradation and biodiversity loss and the latter to pressures from livelihood practices and patterns that may lead to the over-exploitation of natural resources, including fisheries, aquaculture activities, fuel collection and grazing in addition to changes in human population density and the poverty dynamics. Management of these threats has been hindered by a lack of up-to-date and relevant scientific data to support conservation policies and their effective implementation.

At the latter phase of the project capacity building module for decision makers was also proposed, and a mechanism for making the outputs available through the Internet outlined.

\section{Site Description}

The western coastline of Sri Lanka to the north of the major city of Colombo comprises a densely populated, highly urbanised and industrialised part of the country. The MMNL is a micro-tidal estuary and an extended marshland that together comprises a complex coastal wetland system. This system that has long been used for cultivation and in recent times for industrial development and aquaculture activities. The marsh (3100 ha in area) adjoins the estuarine lagoon (3200 ha) in the northwest (Mahanama, 2002; Fig. 1). It counts as one of 12 priority wetlands with the northern part declared as a 'wetland sanctuary' (Euroconsult, 1994). The fresh water source for the lagoon and marsh is Dandugan Oya (a river with a catchment of $727 \mathrm{sq} \mathrm{km}$ ). The marsh is crossed by canals (the Dutch and Hamilton canals) that were constructed during the colonial period for irrigation. In addition to its unique ecological value (in terms of floral and faunal diversity) the region is of major socioeconomic importance through the provision of food and income to many local people. Administratively, the MMNL is located in the Gampaha District (Western Province) covering four administrative divisions (DS-Divisional Secretariat level) viz, Ja Ela, Wattala, Katana, and Negombo which further includes 85 Grama Niladari (GN) divisions [the smallest administrative unit in Sri Lanka]. The northern end of the lagoon is in Negombo and the southern in the Ja Ela and Katana DS. The Muthurajawela Marsh is mainly in the Wattala-DS. The Bandaranaike International Airport in Katana and the open (free) trade zone in Ja-Ela both with significant infrastructure development activities that have timely contributed to the extensive economic development and population growth of the region in the last few decades the 2001 census report shows that the Gampaha district has a $48 \%$ increase in population between 1981 and $2001\}$.

Over the past two decades the wetland system underwent major environmental change viz., encroachment and infilling of the marsh, heavy industrialisation, lagoon and canal sedimentation that has severely affected the water flow and biodiversity profile of the wetlands (Euroconsult, 1994). UNEP (2001) also reported that $80 \%$ of industries in the country are based in the Colombo and Gampaha Districts. In summary, although such barrier built estuaries are destined to change into a system of tidal creeks with time, the interval being influenced by several hydrological variables as explained by (Perkins, 1974; Dyer, 1973). In the present case the human pressure has actually aggravated the natural change, which is an inherent characteristic of barrier-built estuaries such as Negombo Lagoon. To sum, these increasing pressures make MMNL more and more vulnerable. As a consequence the CEA, the state regulatory, has sought partnerships to investigate the extent of ecological and socio-economic change and develop a geospatial monitoring system for identifying spatial and social trends in the wetland complex.

\section{METHODS}

The concept of linking multi-disciplinary knowledge and information was used as a base for 
designing a geospatial model for wetland mapping and modelling. The analyses that supported the model were broadly divided into two components. The first was at a Divisional Secretariat (DS) level and included mapping of wetland communities and change analysis to identify critical threats and indicators and outline key actions required to promote sustainable and wise use of wetlands resources. This was done using the LCM (land change modeller) application of IDRISI-Andes. The in-built modules in LCM (net change and interchange statistics) provide a pathway to identify indicators of wetland loss. Ground control points (GCPs) collected using a differential GPS (Global Positioning System), pre- (23) and postclassification (58) were used to define the test signature for the supervised classification and to support the accuracy assessment (using Kappa statistics). In the geospatial analysis the biophysical and socioeconomic details were combined to produce a land cover/use map of the wetland complex. The analysis of the first component contributed to the selection of a site for the second component, namely detailed analysis at the household level (undertaken in Seedawatte village).

\section{Component 1: Landscape level analysis for Muthrajawela marsh-Negombo lagoon}

Due to the imprecision and uncertainty in classifying and monitoring wetland communities an automated semi-supervised classification approach was used to spatially capture changes in land use (Nagabhatla et al., 2007). Multi-temporal (1987, 1992 \& 2002) Landsat TM satellite images were used for the land change analyses with the addition of further data and existing topographic maps (Topo sheet Number 59 Negombo Published by the Survey Department of Sri Lanka, First Edition 1990). Temporal images were identified by processing and classifying the digital data using supervised classifier in ERDAS 9.2 [Maximum Likelihood algorithm]. The scale of classification was $1: 50,000$ and the projection system UTM WGS 84, Zone 44 (Fig. 2). The land cover map at the DS scale (total area of 11,922 ha) was used to describe the major wetland use viz, coconut grove, plantations, semi-natural marshlands and water bodies, and was then used as an input base map for the change analysis process in LCM.

To address wetland change at the landscape level the land cover layer and not the wetland cover map was used in order to capture the transitions between wetland and the adjoining non-wetland communities. For the socioeconomic component of the analyses, secondary data was collected at the GN level to complement the biophysical analysis. A field form with relevant socio-economic parameters for the model was designed based on the sustainable livelihoods (SL) framework [adapted from the DFID model] with a special focus on the five livelihood assets or capital defined in the model - natural, human, social, physical and financial capital (DFID, 2001). The socio-economic primary (male female distribution, livelihood pattern, use of wetland resources) and secondary (population, education, health, sanitation and poverty related information at site/household level) data sets were incorporated into the thematic GIS layers; for example the population density in the $85 \mathrm{GN}$ divisions was grouped into five categorises viz, low (1000-2000), medium (2000-3000), high (3000-4000), very high (4000-5000) and dense (>5000) (Fig. 3).In addition the thematic layers viz, population, road network (proximity buffer analysis) and stream flow were also combined in the ecological sustainability application of the IDRISI-LCM modeller. Different modules in the LCM, for example the 'change analysis', 'net change', 'transition potentials' and 'change prediction tools' were used to produce many intermediate disaggregated products. The conversion between different wetland communities was analyzed using the transition map component of LCM. Finally, the geospatial maps were validated using the GCPs, the socioeconomic data and the information derived from discussions with local governing authorities (DS and GN- divisional offices, climate station).

\section{Component 2: Site Scale Analysis}

The land cover/use base map at the DS scale for 1987, 1992 and 2002 for all the 85 GNs produced during the first component of the analyses was used to select a village (covering 1513.6 ha) for an in-depth spatio-temporal and socioeconomic analysis. A site of interest was selected considering the range of environmental change and the livelihoods parameters. The following criteria were considered pertinent for the site selection process: impact of adverse environmental change/land use change, geographic location (proximity to the lagoon and the marsh), population, amount of households engaged in some form of natural resource (NR) consumption, heterogeneity in levels of poverty (to investigate the association between poverty level and dependency on natural resources); involvement in relevant policy or management processes (impact of policy/management regime of the wetland at the household level) and the age of settlement/village. 
During the first stage of selection seven sites were identified. At the second stage the sites were ranked from 1 to 5 (based on geography/location, heterogeneity, willingness, NR use and so on). The process was further strengthened by the support of multi-criteria analysis (MCA)-decisionmaking tool. In the ranking exercise the prospective site that scored the maximum was from the Maha Pamunugama GN division (the Seedawatte Village). For the livelihoods analyses a Sustainable Livelihoods (SL) framework was adopted to support the data collection process. This approach provides a better understanding of the different aspects of a community's livelihood patterns and factors that govern the process (DFID, 2001). Primary socio-economic data were collected using a combination of participatory methods (such as community mapping of village, wealth ranking exercises and focus group discussions) and a more conventional household survey covering livelihoods and environmental issues.

\section{RESULTS}

\section{Spatial change analysis and livelihood trend in MMNL}

The multi-scalar remote sensing analysis from the first component of the analyses reflects the spatial distribution and the impact of natural and anthropogenic pressure on the micro-tidal estuary. The accuracy of the refined supervised classification approach was 86\%, even though there were ambiguities in delineating closely related vegetation communities viz., marshland with shrub patches and open moist area with shrubs. However, the change analysis revealed that the dominant wetland types viz., lagoon, marsh, abandoned swampy paddy field, are now fragmented and in a degraded state. These changes were qualified (natural and created) and quantified (area) to explain the increase, decrease and interchange in the pattern of wetland uses. Two major temporal changes (from 1987 to 2002) were the conversion of the lagoon to a shallow water body (caused by the natural sedimentation processes, mainly from land drainage, and from tidal inflow, result in deposition and accumulation as explained by Samarakoon and Van Zon (1991). This statement was also supported by the Euroconsult (1994) report. In addition the sedimentation from the domestic and industrial sector adds to the sedimentation process.

On the second note, the contraction and conversion of the marshland to built up areas (settlements and industrial zone) areas (Fig. 4) is a notable change. Additionally, the spatial analysis also depicts the change from agricultural (paddy fields) to semi-naturalized marsh/grassland as a prominent transition. Also, the aerial statistics from the temporal remote sensing images analysis shows decline in deep lagoon zone, littoral vegetation and swampy marsh ( Table 1).

In 1987 the MMNL did not have protected area status with agriculture being the dominant wetland use, supported by fresh water irrigation canals (the Dutch and Hamilton canals). The canals along with the ties and the river flows are the main contributors to lagoon flushing that facilitated the hydrological flow in the wetland system. Further, in 1992 the marsh was declared as a wetland sanctuary (protected area), this legal delineation of the region along with the natural interventions governed the associated change in the land use pattern. For instance, the change in the rice dominated agricultural system was adversely affected by an increase in salinity supposedly caused by an influx of saline water from the sea through the canals that in particular is evident by spatial image from 1992. However, it could be reasoned that the declaration of the marsh area as a sanctuary also had some impact on the surrounding agricultural belt, although the major instance was the salinity reasons.Over time the abandoned fields were invaded by opportunistic plant species, especially grasses and a few shrubs that gradually led to the formation of swamp/marsh, as shown in the 2002 data (Table 2).

Furthermore, the analysis of change using different thresholds and defined algorithms in IDRISI was used to depict the contribution of individual changes to net change and the overall change in the land cover/use. For example, the abandoned paddy (Fig. 5a) was converted to marshland followed by an increase in the area of the littoral vegetation. Similarly, Fig. 5b shows the loss of other land cover/uses that led to an increase in the area of settlements. Increasing urbanisation and industrial growth were identified as the main driver for the loss or/and shrinkage of the marshland.

In addition the socioeconomics at DS level reveal that the industrial sector concentrated in the Ja Ela, Wattala and Katana DS divisions is the main livelihood provider (Fig. 6). Fishing activities are prominent only in the Negombo division that includes the Negombo Lagoon area. Information through focal group discussion was used to validate the spatial analysis; for example 
the residents confirmed that along with the tidal sediment deposition in the micro-tidal estuary the industrial, domestic and agricultural discharge over years has disturbed the pattern of water flow into the lagoon. Apparently the social impact of the biophysical change, such as increased sedimentation (in the lagoon) is assumed to have unfavourably affected the fish productivity and hence the livelihood pattern of the local people. Also, with time, the rice fields were abandoned forcing the agricultural community to shift to other livelihood activities. At the same time the expansion of industry around the periphery of the wetland complex provided alternative livelihood opportunities that are leading to an increase in built up/settlement areas in the vicinity of the marshland. The pattern of transition in the region provides insight to a highly dynamic phenomenon of spatial versus social changes that although intricately linked are thinly explored.
Spatial analysis and socio-economic dynamics for Seddawatte Village

The temporal changes around the Seddawatte village-situated in close proximity to the Negombo lagoon, Hamilton Canal and the marsh area provide a holistic understanding of the system dynamics at village scale. There have been important changes in the wetland cover/use pattern during the period under investigation (1987-2002); these changes have been observed and experienced by local communities and also had a significant impact on their overall livelihood system. Several observations comparable to those made for the MMNL were recorded. Figure 7 clearly depicts that in 1987, the landscape was intact with fresh water flow, significant agroecological diversity and a healthy lagoon-marsh interaction. It was seen that sedimentation in 1987 was not as extreme as in the later years. During 1992 the increase in settlement area and the change in the littoral zone of the landscape were noted. Furthermore, in 2002 the landscape was fragmented as a result of growing anthropogenic interventions (Table 3).

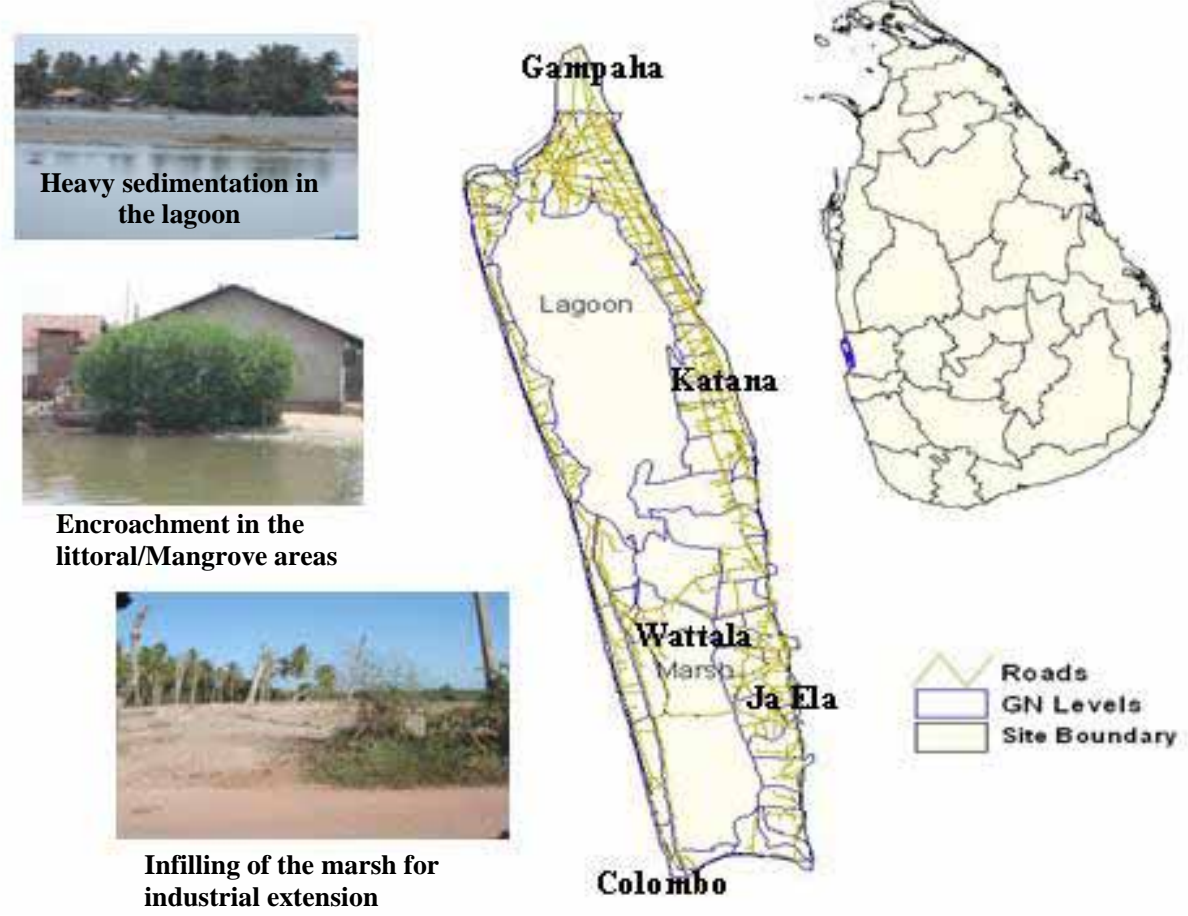

Figure 1. Muthrajawela marsh-Negombo lagoon [MMNL] with Divisional Secretariat [DS] levels and Grama Niladari [GN] divisions, road network providing insight on the issues of environmental concern. 
Table 1. Spatial change analysis and livelihood trend in Muthrajawela Marsh-Negombo Lagoon [MMNL] from 1987-2002

\begin{tabular}{|c|c|c|c|c|c|c|}
\hline \multirow{2}{*}{$\begin{array}{l}\text { Wetland } \\
\text { cover type }\end{array}$} & \multicolumn{3}{|c|}{ Area in hectares } & \multirow{2}{*}{$\begin{array}{l}\text { Overall } \\
\text { trend }\end{array}$} & \multirow{2}{*}{$\begin{array}{l}\text { Potential impact } \\
\text { of change on the } \\
\text { wetland ecology }\end{array}$} & \multirow{2}{*}{$\begin{array}{l}\text { Potential impact } \\
\text { of change on } \\
\text { livelihoods of } \\
\text { community }\end{array}$} \\
\hline & 1987 & 1992 & 2002 & & & \\
\hline $\begin{array}{l}\text { Lagoon/ Deep } \\
\text { water }\end{array}$ & 492.8 & 435.3 & 410.6 & Decrease & $\begin{array}{l}\text { Negative impact on } \\
\text { the breeding grounds } \\
\text { of fish and shrimp } \\
\text { species; natural } \\
\text { systems of water } \\
\text { filtration/purification } \\
\text { affected }\end{array}$ & $\begin{array}{l}\text { Negative impact on } \\
\text { lagoon fishing; } \\
\text { decrease in income }\end{array}$ \\
\hline Shallow water & 139 & 145.3 & 154.1 & Increase & $\begin{array}{l}\text { Increase in sediment } \\
\text { in lagoon }\end{array}$ & $\begin{array}{l}\text { Negative impact on } \\
\text { lagoon fishing; } \\
\text { decrease in income }\end{array}$ \\
\hline $\begin{array}{l}\text { Littoral } \\
\text { vegetation }\end{array}$ & 231.4 & 266.8 & 291.9 & Increase & $\begin{array}{l}\text { Increased breeding } \\
\text { grounds for fish and } \\
\text { shrimp species, } \\
\text { natural system of } \\
\text { water } \\
\text { filtration/purification, } \\
\text { buffer against } \\
\text { flooding }\end{array}$ & $\begin{array}{l}\text { Provides fishing } \\
\text { gear, firewood, feed } \\
\text { for livestock, }\end{array}$ \\
\hline $\begin{array}{l}\text { Marshland/ } \\
\text { Shrubs }\end{array}$ & 395.9 & 458.5 & 411.5 & $\begin{array}{l}\text { Increase/ } \\
\text { decrease }\end{array}$ & $\begin{array}{l}\text { Fragmentation of } \\
\text { marsh, negative } \\
\text { impact on species } \\
\text { habitats; impact on } \\
\text { buffer against } \\
\text { flooding }\end{array}$ & $\begin{array}{l}\text { Main source of } \\
\text { firewood } \\
\text { diminishing; fodder } \\
\text { for livestock } \\
\text { diminishing }\end{array}$ \\
\hline $\begin{array}{l}\text { Grassland } \\
\text { (paddy/ } \\
\text { abandoned } \\
\text { fields) }\end{array}$ & 135.9 & 63.3 & 23.4 & Decrease & $\begin{array}{l}\text { Conversion of } \\
\text { agrarian zone to } \\
\text { semi-naturalized } \\
\text { grassland region }\end{array}$ & $\begin{array}{l}\text { Paddy cultivation } \\
\text { being abandoned; } \\
\text { grazing for livestock, } \\
\text { conversion to home } \\
\text { gardening }\end{array}$ \\
\hline $\begin{array}{l}\text { Home } \\
\text { gardens } \\
\text { (coconut) }\end{array}$ & 95.7 & 117.1 & 183.2 & Increase & $\begin{array}{l}\text { Fragmentation of } \\
\text { marsh, negative } \\
\text { impact on species } \\
\text { habitats }\end{array}$ & $\begin{array}{l}\text { Subsistence purposes } \\
\text { helps improve } \\
\text { overall livelihood } \\
\text { system; home } \\
\text { consumption, } \\
\text { addition for } \\
\text { improved food } \\
\text { security }\end{array}$ \\
\hline $\begin{array}{l}\text { Settlements/ } \\
\text { Built -up }\end{array}$ & 22.9 & 27.3 & 38.9 & Increase & $\begin{array}{l}\text { Fragmentation of } \\
\text { marsh, negative } \\
\text { impact on species } \\
\text { habitats }\end{array}$ & $\begin{array}{l}\text { More development } \\
\text { within the } \\
\text { settlement ; improves } \\
\text { the general } \\
\text { infrastructure of the } \\
\text { village (roads, } \\
\text { electricity, water); } \\
\text { provide homes for } \\
\text { encroaches of } \\
\text { marshland, improved } \\
\text { sanitation, poverty } \\
\text { alleviation }\end{array}$ \\
\hline
\end{tabular}




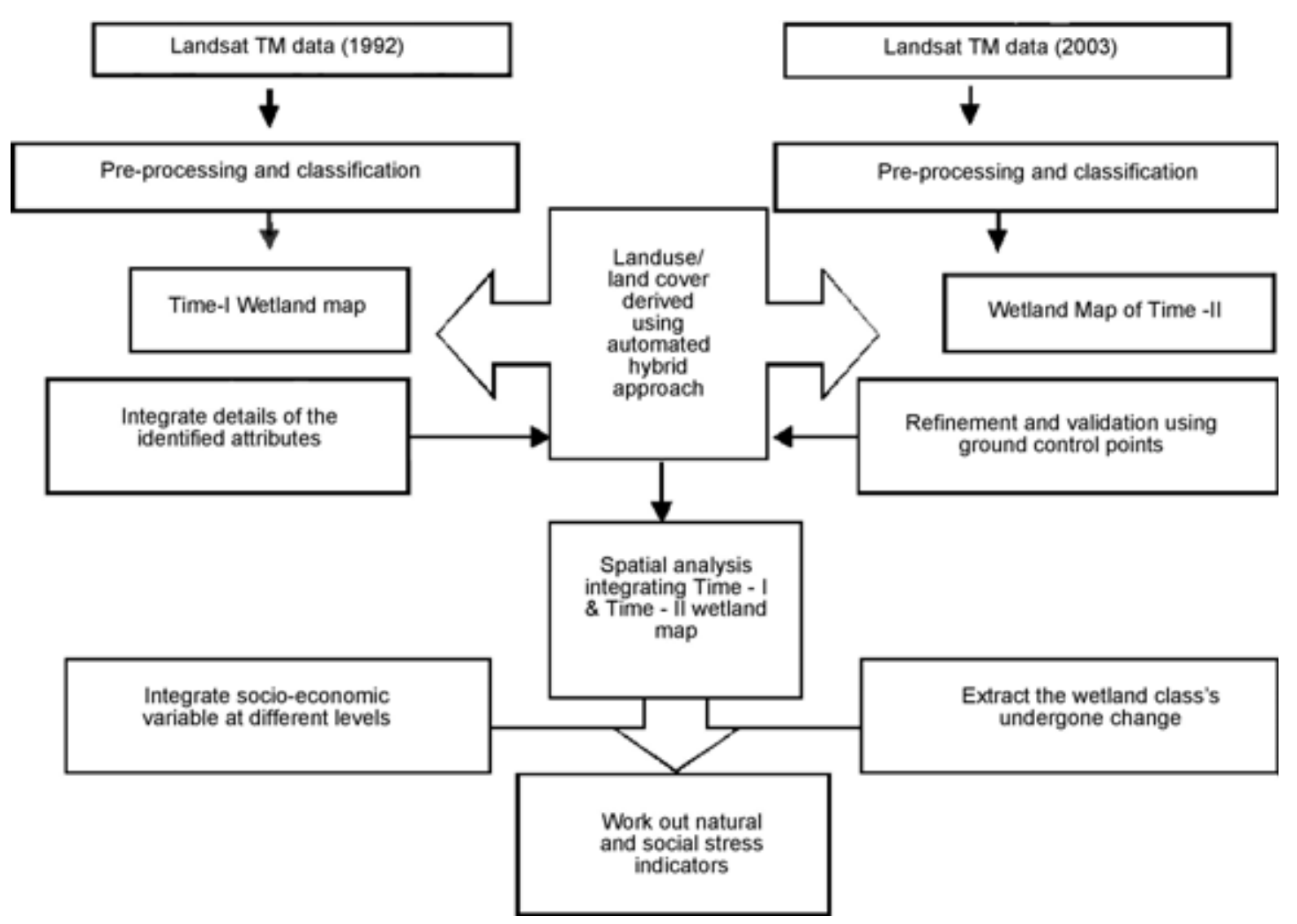

Figure 2. The process involved for analyses of land use change by linking ecological and socioeconomic variables.
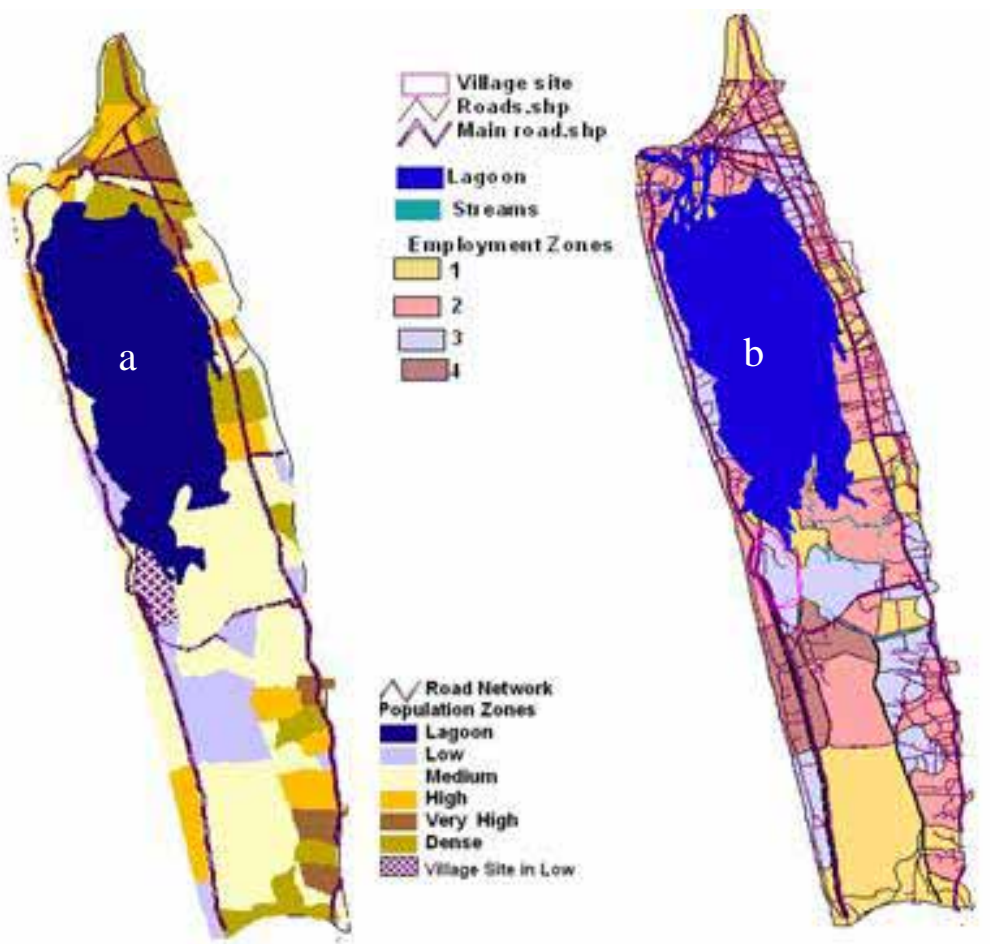

Figure 3. Thematic geospatial layers for population density (a) and employment level (b); the secondary layers integrated in the geospatial model for assessing dynamics of change. 


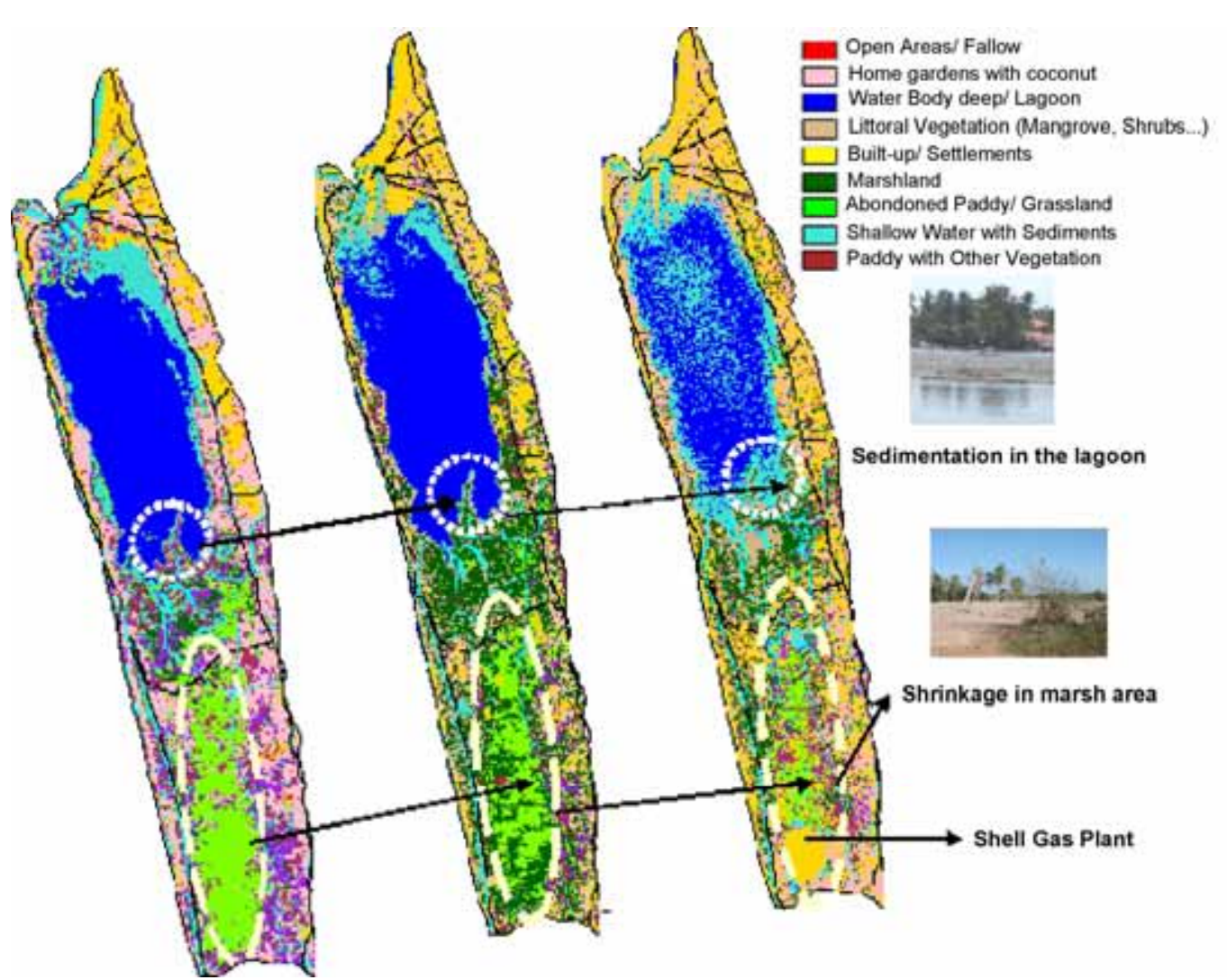

Figure 4 Change analyses in the lagoon-marsh wetland complex at the landscape level highlighting two predominant changes

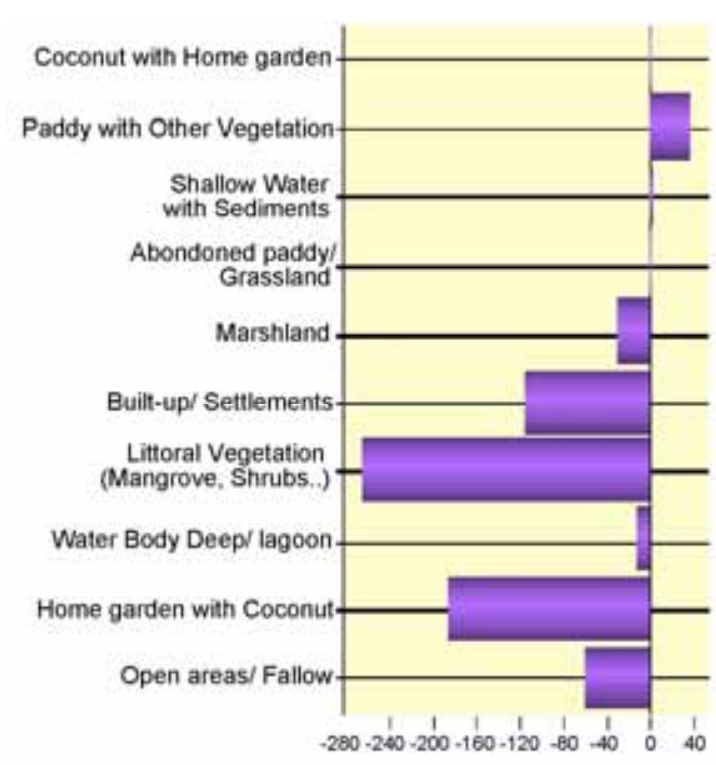

a

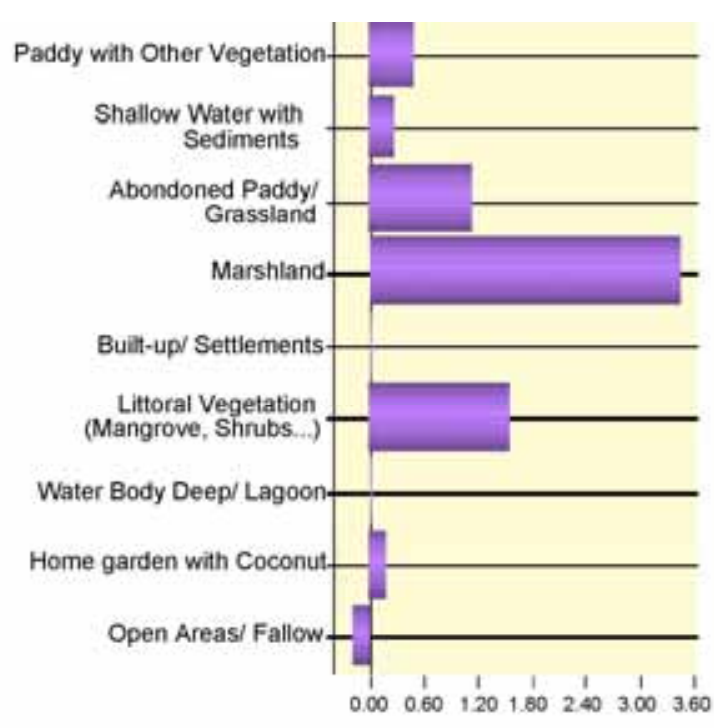

$\mathrm{b}$

Figure 5. Depicting two scenarios from the change analysis a) Contribution to net changes in abandoned Paddy / Grassland (area in Ha), b) Contribution of changes in other land cover (use) to increased area of settlements (in $\mathbf{~ k m}^{2}$ ) 


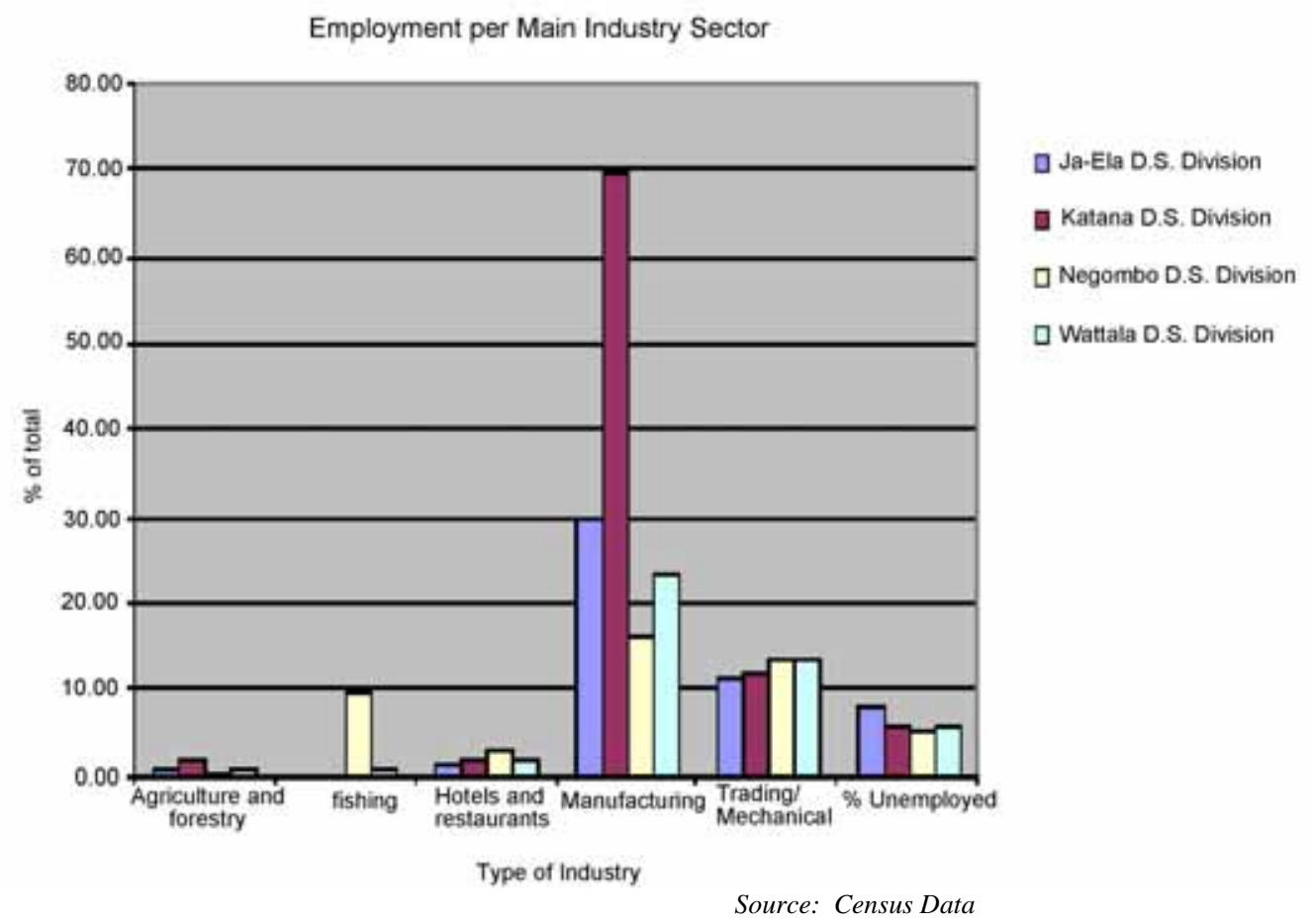

Figure 6. Distribution of employment per sector at the Divisional Secretariat level reflecting the dominance of fishing activity in the livelihood activity in the Negombo Lagoon

Table 2. Status of land cover /use change in the wetland complex from 1992-2002.

\begin{tabular}{|c|c|c|c|}
\hline $\begin{array}{l}\text { Wetland } \\
\text { cover type }\end{array}$ & $\begin{array}{l}\text { Change in } \\
\text { area (ha ) } \\
\text { 1992-2002 }\end{array}$ & $\begin{array}{l}\text { Status of } \\
\text { change from } \\
1992-2002 \\
\end{array}$ & Benefits: ecological and socio-economic \\
\hline $\begin{array}{l}\text { Water body/ } \\
\text { Lagoon }\end{array}$ & -24.7 & -- & $\begin{array}{l}\text { Lagoon fishing, breeding grounds for fish } \\
\text { species, natural system of water } \\
\text { filtration/purification }\end{array}$ \\
\hline $\begin{array}{l}\text { Shallow water / } \\
\text { Canals }\end{array}$ & 8.8 & + & $\begin{array}{l}\text { fishing, bathing, landing site for boats, water } \\
\text { discharge }\end{array}$ \\
\hline $\begin{array}{l}\text { Mangroves / } \\
\text { Scrubland (littoral) }\end{array}$ & 25.1 & +++ & $\begin{array}{l}\text { Fishing gear, firewood, feed for livestock, } \\
\text { breeding grounds for fish species, natural } \\
\text { system of water filtration/purification, buffer } \\
\text { against flooding }\end{array}$ \\
\hline Marshland & -47 & ---- & $\begin{array}{l}\text { Grazing for livestock, firewood, natural } \\
\text { system of water filtration/purification, buffer } \\
\text { against flooding }\end{array}$ \\
\hline $\begin{array}{l}\text { Grassland(abandon } \\
\text { ed paddy ) }\end{array}$ & -39.9 & -- & $\begin{array}{l}\text { Grazing for livestock, conversion to home } \\
\text { gardening }\end{array}$ \\
\hline $\begin{array}{l}\text { Home garden with } \\
\text { Coconuts }\end{array}$ & 66.1 & ++++ & $\begin{array}{l}\text { Home consumption, addition for improved } \\
\text { food security }\end{array}$ \\
\hline Settlements & 11.6 & ++ & $\begin{array}{l}\text { Provide homes for encroaches of marshland, } \\
\text { improved sanitation, poverty alleviation }\end{array}$ \\
\hline
\end{tabular}

The change benefit ratio is scaled as shown (+ small increase, ++ medium increase, +++ moderate increase, ++++ significant increase; - low decrease, -- medium decrease, --- significant decrease). 


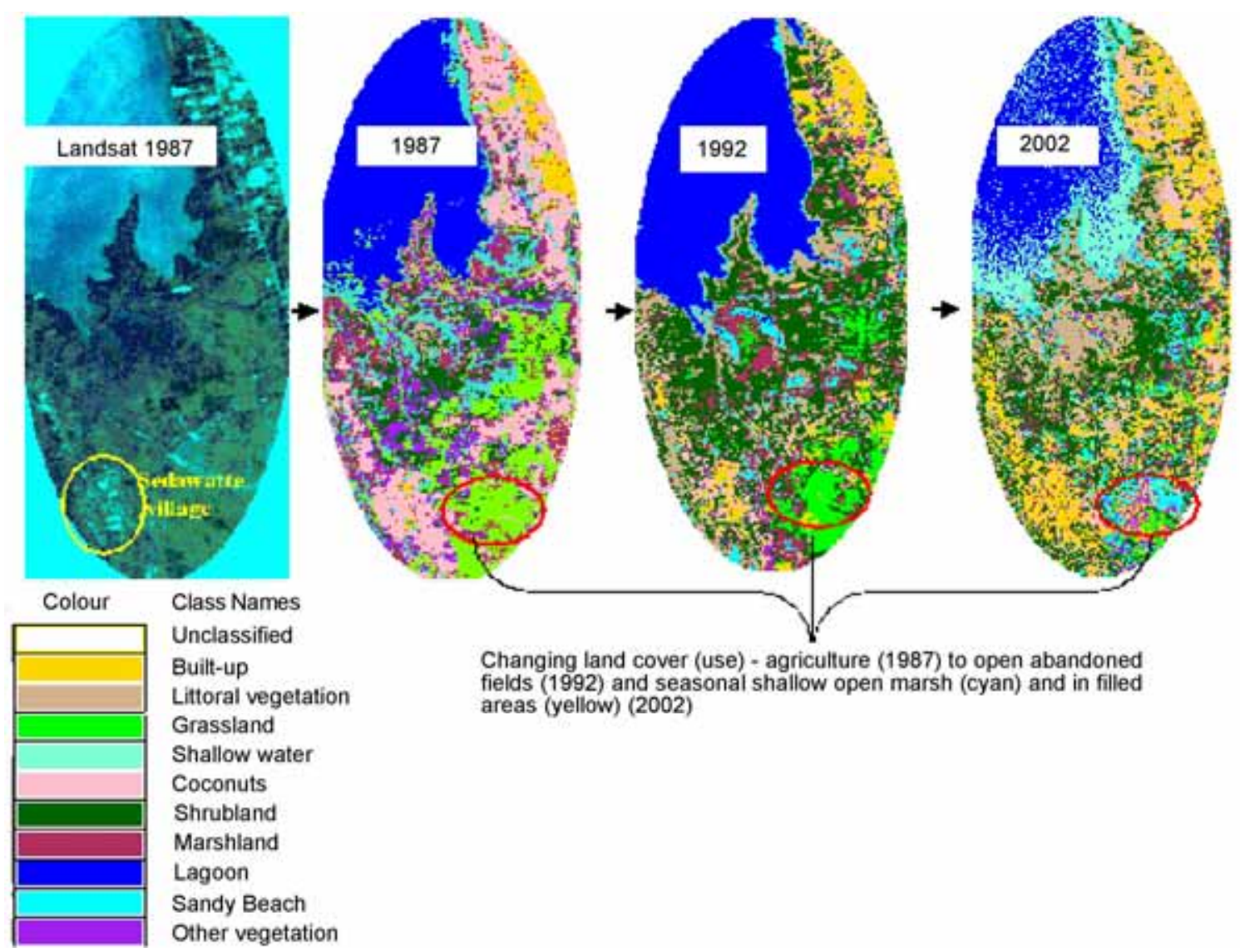

Figure 7. Temporal analyses at the Sedawatte village and surrounding landscape using Landsat data

Table 3. Spatial analysis for Seedawatte Village

\begin{tabular}{lccc}
\hline Site analysis & \multicolumn{3}{c}{ Area in ha } \\
\cline { 2 - 4 } & $\mathbf{1 9 8 7}$ & $\mathbf{1 9 9 2}$ & $\mathbf{2 0 0 2}$ \\
\hline Shallow water & 139.0 & 145.3 & 154.1 \\
Marshland / Shrubs & 395.9 & 455.5 & 411.5 \\
Lagoon/ Deep water & 492.8 & 435.3 & 410.6 \\
Littoral vegetation & 231.4 & 266.8 & 291.9 \\
Home gardens ( coconut) & 95.7 & 117.1 & 183.2 \\
Grassland ( paddy/ abandoned fields ) & 135.9 & 63.3 & 23.4 \\
Settlements/ Built -up & 22.9 & 30.3 & 38.9 \\
\hline
\end{tabular}

An interesting ecological pattern was the increase in the littoral zone; accredited to the growth of more salt tolerant mangrove associates (e.g. Acrosticum aurium) that have spread over the region in the highly saline marsh zone substituting the true mangrove (Rhizophora apiculata ,Bruguiera gymnorhiza ) species. It has also been noted that Acrosticum aureum the fern species, grows in areas where mangroves vegetation is removed and the generation time of a fern is very 
short compared with that of a mangrove seedling. This phenomenon has also been explained by Dahdouh-Guebas et al. (2005) as 'cryptic ecological degradation'.

Also, the lagoon area had notably decreased between 1987 and 2002; this spatial observation was corroborated during FGDs held with members of the community engaged in lagoon fishing. The second important observation was the increase in settlement areas from 1987 onwards and likewise an increase in the total home garden area (coconut groove). This was validated by the household survey undertaken in Seedawatte village and the demographic data gathered at the village level. An interesting observation was the increase in marshland area between 1987 and 1992 that was followed by a decrease in 2002 (Table 3). This can be explained by changes in the water regime; first from 1987 to 1992 the region was under the influence of frequent local flooding and inter-tidal fluctuations resulting in seasonal saturation or water-logging; second the abandoned agriculture fields were in the transition phase of being converted into marshland, hence contributing to an overall increase of the marsh area. However after 1992, the water regime and the physiological conditions turned most of the abandoned area into semi-naturalized wetland communities (grassland dominated by Phragmites karka and Typha augustifolia) largely resulting in change of areal statistics of the marshland. In the context of the livelihood pattern, the Seedawatte village can be compared with the general pattern observed at the DS level. It was inferred that only a small percentage of the households are dependent on natural resources based primary livelihood activities. Whilst the questionnaire survey reflected that the communities and households depend on natural resources for subsistence (Table 4) and up to 67 percent of households directly use the adjoining marsh for firewood while only a minor percent use the wetland species (Typha augustifolia and Phragmites karka ) for fencing roofing/thatching. In addition the region serves as grazing ground for the cattle and in some cases provides raw material to generate alternative income through mat weaving.

In Seedawatte, fishing in the lagoon was mainly for the purpose of home consumption. Also, small-scale aquaculture (fish, crab and shrimp) is practiced by the local communities at a subsistence level. In terms of rating the spatial environmental changes that had occurred in each of these systems (landscape level and site scale) over the past 15 years, a majority of respondents were of the opinion that the change in the lagoon, canal and the marsh area had been for the worse. For example, the FGDs held with fishermen in Seedawatte showed that in terms of the magnitude of the different environmental issues the fishermen faced, they were of the view that the decrease in lagoon depth was the most serious.

Table 4. Socio-economic analysis for the Seedawatte village with employment spectrum

\begin{tabular}{lccc}
\hline $\begin{array}{l}\text { Occupation } \\
\text { categories }\end{array}$ & $\begin{array}{c}\text { Number of } \\
\text { Households }\end{array}$ & $\begin{array}{c}\text { \% of } \\
\text { sample }\end{array}$ & $\begin{array}{c}\text { Resources } \\
\text { used }\end{array}$ \\
\hline Fisherman & 7 & 5.2 & $\mathrm{~N}$ \\
Retail fishmonger & 6 & 4.4 & $\mathrm{~N}$ \\
Agricultural workers and services & 5 & 3.7 & $\mathrm{~N}$ \\
Labour work & 23 & 17 & $\mathrm{~B}$ \\
Carpenter & 3 & 2.2 & $\mathrm{~B}$ \\
Mason & 4 & 3 & $\mathrm{~B}$ \\
Service workers \& shop and market sales & 16 & 11.9 & $\mathrm{~B}$ \\
workers & & & \\
Driver & 15 & 11.1 & $\mathrm{~B}$ \\
Factory work & 3 & 2.2 & $\mathrm{I}$ \\
Garment worker & 5 & 3.7 & $\mathrm{I}$ \\
Government worker & 5 & 3.7 & $\mathrm{~B} / \mathrm{O}$ \\
Private sector worker & 9 & 6.7 & $\mathrm{I}$ \\
Overseas & 4 & 3 & $\mathrm{O}$ \\
Pensioner & 2 & 1.5 & $\mathrm{O}$ \\
Unemployed & 28 & 20.7 & $\mathrm{O}$ \\
Total & $\mathbf{1 3 5}$ & $\mathbf{1 0 0}$ & \\
\hline
\end{tabular}

$\mathrm{N}$ : Natural resource; B/O: Business/ Others; I: Industrial 


\section{DISCUSSION}

The gradients of change at diffrent management levels (DS, GN and household) reflect significant connections between the spatial patterns and the socioeconomic dynamics. To support global (Ramsar) and the local (CEA) vision of managing wetland systems, the discussion outlines a holistic ovewiew of a geospatial tools combining different operational disciplines (such as ecology, socioeconomics and hydrology) to address the management issues in an urbanized coastal wetland. Although, studies by Jayatissa et al. (2002) and Dahdouh-Guebas et al. (2005) covered ecosystem aspects using spatial analysis with an initial attempt to link these with socioeconomic data. However, these efforts were hindered by a lack of quantitative associations (White and Nackoney, 2003). Given this backdrop, the present study combines the ecological spectrum and socioeconomic parameters to qualitatively derive meaningful information on the impact of change and/or transition in resource systems and address the environmental issues taking micro-tidal estuary as a representative system.

The spatial statistics at the landscape level reflects that the gradual sedimentation process of the lagoon driven both by tidal flow and external drainage has pertinently resulted in the shrinkage of the deep water lagoon from 492.8 ha in 1987 to 410.6 ha in 2002. While at the site scale for the Seedawatte village it was seen that for the surrounding land cover an increase in marchland has been seen, whilst the abandoned paddy land had shrunk. This was an interesting observation quite comparable to the situation at the landscape level. It can be explained that abandoned paddy fields have over time naturalised into seasonal to sub-seasonal marshy areas. This is also validated by minor percentage (3.7\%) that is engaged in agricultural activities as farmers or /and frame labours. In addition the spatial analysis also provides an understanding of the dynamics governing the systems response to change. Information on the pattern and trends of change viz., the conversion of marshland to build up area represent the degree of alteration in the wetland (use). This alternation is governed both by natural process and anthropogenic influences. These alternations in the landscape have slowly but gradually resulted in flooding, livelihood insecurity and health related problems while the long-term impacts are reduced water retention and disturbance of the environmental water balance and flow. The temporal change validated using the synthesized information from primary and secondary socio-economic data highlights the adverse impact of environmental change on livelihood activities.

Additionally, the study demonstrates the application of geospatial techniques to provide a multidisciplinary approach to understand change in a barrier built estuary that represents a small and shallow micro-tidal regime. Though the approach provides a 'bird's eye view' of change for the micro-tidal system the approach can be rescaled and customised for the similar estuaries in meso and macro-tidal regimes while also accounting the spatial resolution and the behaviour of the tidal prism. Also, the adopted geospatial approach based on a multi-disciplinary framework provides an effective tool to address and monitor multiple environmental changes and assist in management planning. It is likely that sustainable management of the marsh-lagoon complex will be enhanced through advanced tools and technologies, knowledge transfer and communication gateways (World Wide Web, reports), multi-stakeholder participation and enhanced levels of awareness, skilfully combined with a long-term vision. Finally, we contend that regular monitoring of resource systems can play an important role in effective and efficient management. As well, the geospatial analysis based on Earth Observation data has the potential to integrate socio-economic components to address environmental issues in an integrated manner and address institutional and policy gaps in the process of economic expansion and sustainable management.

\section{ACKNOWLEDGMENTS}

The authors would like to thank Dr Robert Zomer, for timely inspiration and discussions on the subject. We are also grateful to the members of Central Environmental Authority, Sri Lanka for their support for the fieldwork and analysis. We acknowledge the cooperation extended by the community members in the wetland site during the socioeconomic data collection and would also like to express sincere thanks to all other local government agencies for their valuable time and information provided. Also, the constructive suggestions provided by the anonymous reviewers are gratefully acknowledged. 


\section{REFERENCES}

ADB, (2005). Post-Tsunami Recovery Program: Preliminary Damage and Needs Assessment. Asian Development Bank, Colombo, Sri Lanka

Bambaradeniya, C.N.B., Ekanayake, S.P., Kekulandala, L.D.C.B., Samarawickrama, V.A.P., Ratnayake, N.D. and Fernando R.H.S.S. (2002). An assessment of the status of biodiversity in the Muthurajawela wetland sanctuary. Occasional Papers of IUCN Sri Lanka, Colombo, Sri Lanka.

Dahdouh-Guebas, F., Jayatisse, L.P., Di Nitto, D., Bosire, J.O., Lo Seen, D. and Koedam, N. (2005). How effective were mangroves as a defence against the recent tsunami? Current Biology 15 (12): 443-447.

Department of Census and Statistics, Sri Lanka, (2004). 15/12, Maitland Crescent, Colombo World Wide Web: http://www.statistics.gov.lk/

Department for International Development (DFID) (2001). Sustainable Livelihood Guidance Sheets. http://www.livelihoods.org/

Dyer, K.R. (1973). Estuaries: A physical introduction. Wiley-Interscience, New York and London.. Pp. I40.

Euroconsult (1994). Master plan of Muthurajawela and Negombo Lagoon. Greater Colombo Economic Commission and Euro consult, Colombo, Sri Lanka.

Finlayson, C.M., Begg, G.W., Howes, J., Davies, J., Tagi K. and Lowry, J. (2002). A Manual for an Inventory of Asian Wetlands (Version 1.0). Wetlands International Global Series 10, Wetlands International, Kuala Lumpur, Malaysia Pp.72.

Finlayson, C.M., Zomer, R., Nagabhatla, N., and Rebelo, L.M. (2006) .Global Wetland Inventory and Mapping; In Water Figures-Turning Research into Development, Issue 3, IWMI, Colombo, Sri Lanka. Pp.6.

Finlayson, C.M. (2007). Managing wetland ecosystems - balancing the water needs of ecosystems with those for people and agriculture. In King C, Ramkissoon J, Clusener-Godt M \& Adeel Z (eds), Water and Ecosystems: Managing Water in Diverse Ecosystems to Ensure Human Well-being, UNU-INWEH, Hamilton, Canada Pp. 24-38.
Hoogvorst, A., (2003). Survival strategies of people in a Sri Lankan wetland: livelihood, health and nature conservation in Muthurajawela. Wageningen University, Wageningen, The Netherlands. Pp. 185.

Integrated Resources Management Programme (IRMP) in Wetlands. (2003) Final Project Completion Report. Prepared by Central Environmental Authority (CEA)/Arcadis Euroconsult. Ministry of Environment and Natural Resources, Colombo, Sri Lanka.

IUCN Sri Lanka (2003). Wetland Conservation in Sri Lanka. Proceedings of the Symposium on Wetland Conservation and Management. Organised by the Ministry of Environment, Colombo, Sri Lanka.

IUCN Sri Lanka, Central Environmental Authority (2006). National Wetland Directory of Sri Lanka. Colombo, Sri Lanka.

Jayatissa, L.P., Guero, M.C., Hettiarachchi, S. and Koedam, N. (2002). Changes in vegetation cover and socio-economic transitions in a coastal lagoon (Kalametiya, Sri Lanka), as observed by teledetection and ground truthing can be attributed to an upstream irrigation scheme. Environment, Development and Sustainability 4: 167 - 183.

Mahanama, P.K.S. (2002). Establish the socioeconomic factors that result in the current pattern of human exploitation of the coastal wetlands. Effective Management for Biodiversity Conservation in Sri Lankan Coastal Wetlands: Socio-economic impacts. Darwin Initiative, University of Portsmouth, UK and University of Moratuwa, Sri Lanka. Final report A-IX.

Millennium Ecosystem Assessment Report (2005).The Millennium Ecosystem Assessment: Ecosystems and Human Well-being: Opportunities and Challenges for Business and Industry, Washington DC, USA

Nagabhatla, N., Finlayson, C.M., Selamuttu, S.S., Zomer, R. and Diphoorn L. (2006).Wetland Dynamics-Links with spatial, ecological, livelihoods and gender related issues in the western coastal belt of Sri Lanka. In Proceedings of the Ninth Biennial Conference on "Ecological Sustainability and Human Well-Being". 15-18 December 2006, New Delhi, India.

Nagabhatla, N., Finlayson, C.M. and Selamuttu, S.S. (2007). Spatial dynamics versus social dynamics: understanding trade-offs in ecological 
and socio-economic systems. Development Issues of Environment, (Ed.) Dr Gunjan Malhotra, Macmillian Publishers, New Delhi, India (in Press).

Perkins, E. J. (1974). The biology of estuaries and coastal waters. Academic Press, London and New York.. Pp .ix + 678 .

Ramsar Convention on Wetlands.(1971), Resolution IX.9 of the 9th Conference of the Contracting Parties, Uganda, 8 to 15 Nov. 2005 (www.ramsar.org).

Rebelo, L.M, Finlayson, C.M. and Nagabhatla, N. (2008) Remote sensing and GIS for wetland inventory, mapping and change analysis. Journal of Environmental Management (In Press)..

Samarakoon, J.I. and . Van Zon, H. (1991). The ecological profile of Muthurajawela Marsh and Negombo Lagoon. Colombo, Sri Lanka, GCECEuroconsult. Board of Investment.

UNEP (2001).State of Environment Sri Lanka 2001.United Nations Environment Programme and RRCAP, Colombo Sri Lanka

White, R.P. and Nacknoney, J. (2003). Drylands, People, and Ecosystem Goods and Services: A Web-based Geospatial Analysis. World Resource Institute, Washington, D.C.,USA. 